\title{
CORPORATE GOVERNANCE IN JORDAN: INSTITUTIONAL BACKGROUND AND LITERATURE REVIEW
}

\author{
Khaleel Al-Daoud, Alaa alhorani, Mohammad dabaghia, \\ Zeyad Alkhazali and Ghiath Altrjman
}

\begin{abstract}
This paper attempts to examine the development of corporate governance in Jordan. Past years experienced development in governance structure in Jordan and the attempt of the country to move from the voluntary to mandatory governance structure in the way to improve and enhance the performance of stock market companies in Jordan. Few studies have attempt to examine the corporate governance worldwide, however, Jordan as an emerging market lack of those very rigorous studies that can develop a very comprehensive model to study the influence of corporate governance on the firm performance. Therefore, we try to draw some highlights on trend of recent literature review in the area. Jordan context of corporate governance and related empirical research are discussed here to show the importance of this mechanism to the development of the stock market of the country and protection of the investors. Passing though various development in the field, however, the introduction of mandatory corporate governance principles was the hallmarks of such developments. Empirical research in the context of corporate governance is still at its infancy stage due to the recent mandatory introduction of corporate governance guiltiness. The present research providessome avenues to develop the literature in the area of corporate governance for the context of Jordan. This may provide some guidelines for the research to proceed with the examination of the corporate governance practices and its impact of the performance.
\end{abstract}

Key words: Jordan, Corporate Governance, Performance, Board of director.

Cite this Article: Khaleel Al-Daoud, Alaa alhorani, Mohammad dabaghia, Zeyad Alkhazali and Ghiath Altrjman, Corporate Governance in Jordan: Institutional Background and Literature Review, International Journal of Management, 11(12), 2020, pp. 2706-2716.

http://iaeme.com/Home/issue/IJM?Volume $=11 \&$ Issue $=12$

\section{INTRODUCTION}

Higher income growth rates are achieved in the countries where better corporate governance is entrenched (Škare\&Golja, 2014). The influence of corporate governance on firms' performance 
is noticeable, and its effect on the overall economic health of corporate organizations and society is also apparent. However, news about corporate governance scandals has spread all over the world in the previous years, and consequently the interests of governments, organizations and researchers have been awaken towardsre-investigating the influence of corporate governance on firm performance (Ahmed-Haji \& Mubaraq, 2015; Baydoun, et al., 2013; Marashdeh, 2014). In Jordan like other countries, there was an increasing attention among the various stakeholders including government and investors towards reforms and practices that will enhance the firm performance (Hamdan, 2012).

Howeover, the weaknesses of corporate governance in the developing countries have attracted much attention (Oman et al., 2004; Allen, 2005). Unlike what it takes in the most advanced systems, developing countries with emerging markets may possess a well-developed financial infrastructure, but they are fraught with lesswell-developed processes and systems of accounting, governance, regulation and other financial infrastructure, and less efficient markets. Consequently, greater uncertainty and risk may emerge (Kearney, 2012). Risk and uncertainty, political instability, weak legislation, high levels of government intervention, and low levels of protection for investors constitute the challenges that are being faced by the developing countries (Tsamenyi, et al., 2007). Hence, there is a necessity for effective structures of corporate governance to be adopted (Marashdeh, 2014; Mohammad et al, 2012), and should be firm-specific and contextual (Carcello, Hermanson, \&Ye, 2011).

Both practitioners and scholars have argued that the structure of corporate governance is contextual and firm-specific. The context within which a firm operates determines the kind of corporate governance mechanisms to be adopted (Ararat \& Dallas, 2011). In addition, it has been signified that various facets of emerging markets (e.g. the ownership structure, development of the financial market, and the quality of the public governance) do determine the selection of the elements of corporate governance of the firm (Fan, et al., 2011; Ararat \& Dallas, 2011; Claessens\&Yurtoglu, 2013).

Moreover, the degree of law enforcement is impacted by corporate governance quality, while weak corporate governance will encourage corruptions of different forms to thrive. As such, strong and effective corporate governance has to be established. Therefore, for the developing countries, efforts to establish so under corporate governance are needed as many are still in dire need of appropriate governance (Ekanaakey, Perera\&Perera, 2010). Not only that, Tarraf (2011) has linked the problem of poor corporate governance practices to financial crises. Hence, the subject of corporate governance remains the subject of interest amongst academicians in both developed and developing nations (Reed, 2002; Mallin, 2004; Solomon \& Solomon, 2004). In line with this discussion, this paper aims to discuss the corporate governance development in Jordan and the literature gap. The next section of the paper discussion the institutional development of corporate governance in Jordan, Third section highlight the literature review development and the final section concludes the paper and draw the future directions for the research in corporate governance in Jordan.

\section{CORPORATE GOVERNANCE DEVELOPMENT IN JORDAN}

In the context of Jordan, the global crises which have affected firms around the world have made the stakeholders in Jordan to have a rethink in respect of credibility of the financial reporting of listed companies in Jordan (Hamdan, 2012). Various efforts were put in place to enhance the financial environment of the country. Moreover,the financial sector regulations were reinforced by issuing different laws and the Corporate Governance Code. The reinforcement of the regulations has led to an increase in thenumber of companies listed in ASE from 161 in 2000 to 247 by 2013 (Marashdeh, 2014). In addition, the economy of Jordan has demonstratestable development, witnessed by growing volume of trade and market 
capitalization,which translated into a significant upsurge in the number of firms listed on Amman Stock Exchange [ASE] (ASE, 2012). This reflects the advanced economic liberalization, corporate governance reforms and encouragement of foreign investment enacted by the Jordanian government since the late 1990s.

The establishment of the Amman stock exchang ASE in 1999 for trading public securities, the Securities Depository Centre SDC (which safeguards investors and arbitrates transactions), and theJordan Securities Commission JSC (which regulates and supervises the equity market) have assisted the implementation and codification of legislation and regulations (e.g. the Securities Law of 2002; forerunner of the JCGC in 2006), with the aim of posting investor confidence. Under these legislations and regulations, disclosure and transparency are reinvigorated and investors are protected. The enforcement of the corporate governance regulations are carried out securities commission of stock market under the supervisionof the Ministry of Industry and Trade. Moreover, diverse changes had been witnessed in the regulatory environment since the formation of the ASE, JSC and the Securities Depository Centre (SDC). These three important bodies were formed based on the Securities Law in relation to monitoring, regulating and supervising the companies that are listed in the ASE. The effect of each three bodies had been reinforced with the instructions of Issuing Companies Disclosure, Securities Law of 2002 and Accounting and Auditing Standards for the year 2004. In addition the Co-operative Compliance Authority has achieved much progress by enforcing many basic corporate governance provisions of the Company Law (JSC, 2009).

In addition, to enhance strong corporate governance, Jordanian Securities Commission, (JSC), in 2009, issued the Corporate Governance Code governing the Shareholding Companies Listed on the Amman Stock Exchange which defines and stresses on the responsibilities and formation of the board, its committees and their monitoring roles over the management. Specifically, the code defines the responsibilities of the board of directors as (1) setting strategies, policies, plans and procedures that realize the objectives of the company; (2) taking necessary measures to ensure compliance with the laws in force; (3) setting a risk management policy to address the risks that the company may face; (4) setting procedures that forbid insiders in the company from using inside information to achieve material or moral gains; (5) taking necessary steps to ensure internal supervision on the company's work in progress, including ensuring compliance with the laws in force; (6) reviewing and evaluating the performance of the company's executive management; (7) adopting criteria for granting incentives, compensations, and privileges to members of the board of directors and executive management; and (8) setting a policy to organize relations with stakeholders in a manner that ensures fulfillment of the company's commitments toward them, safeguards their rights, provides them with adequate information, and maintains good relations with them (JSC, 2009).

Moreover, corporate governance code also describes the committees formed by the board of directors such as audit committee. JSC (2009) stipulates that the members of audit committee must have knowledge in finance or accounting, and at least one of them must have worked previously in accounting or finance fields; and that person must have an academic or professional certificate in accounting, finance or related fields. Also, this code ensures audit committee periodically meet and at least one meeting with external auditor must be held.

Nevertheless, studies have noted that the performance level among Jordanian firms is considerably very low, and it has raised concerns among Jordanian regulators and decisionmakers (Almajali, Alamro\& Al-Soub, 2012). The low level of firms' performance, in Jordan, has led to decrease in the level of financial reporting quality, loss of the financial statements' reputation, and it consequently jeopardizes the confidence of shareholders and investors in the shareholding firms (Al-Sraheen, 2014). 
The economic and financial reforms were launched in Jordan for enhancing the financial environment's transparency and accountability so that the country's national economy will increase and improve. Diverse laws on corporate governance are presently available such as Company Law, Securities Law, Insurance Law, Commercial Law, Banking Law, Competition and Monopoly Law, Privatization Law as well as Investment Promotion Law (Al-Jazi, 2007).These laws have contributed to the increase of foreign investors to the local market. In fact, when it comes to luring the foreign investment, Jordan is among the top three countries in the Middle East and North Africa (MENA) (Al-Muhtaseb, 2009).

\section{LITERATURE REVIEW AND THE EMPIRICAL GAP}

It is undeniable that since 1978 a substantial number of empirical researches on corporate governance and firm performance have emerged. However, the current crisis in the global financial realm undermines the importance of corporate governance in resolving global financial crisis (Siddiqui, 2014). This implies that inquiry regarding the benefits of good governance for the modern firms, and relationship between corporate governance and firm performance becomes demanding (Siddiqui, 2014).

Survey of literature on corporate governance-firm performance relationship has demonstrated the existence of inconsistency and inconclusiveness in the findings of the extant research. For example, research (e.g. Ahmed et al., 2013; Rashid \& Islam, 2013; Siagian et al., 2013; Ujunwa, 2012) indicate positive relationship between corporate governance attributes and firm performance. This is clearly demonstrated in the research of Siagian, et al. (2013) in which the finding of study reported a significant positive association between good corporate governance practices and firm value. However, some other studies (e.g. Ahmed-Haji \&Mubaraq, 2015; Hutchinson, 2002; Yammeesri\& Herath, 2010) indicate the otherwise.

The inconsistency and inconclusiveness in the findings of extant corporate governance studies could, to a certain extent, be traceable to the variance in the periods during which those studies were carried out, because the evolving business and economic environment have always brought about inconsistent research results. Also, the inconsistency in the findings of extant research can be somewhat attributed to methodological styles and measures of performance adopted by those studies (Kyereboah-Coleman, 2007). In the longitudinal study carried out by Ahmed-Haji and Mubaraq (2015), it is indicated that all the corporate governance factors (excluding independent chairperson) have a significant negative relationship with one or more measures of corporate performance. Shank et al. (2013) added that the mixed findings in the research on corporate governance can be due to differences in definitions, measurement, and time periods.

According to Skare and Hasic (2016), gauging the influence of corporate governance on the firm's performance and the consequent economic growth is fraught with methodological limitations, and the findings of research across the countries indicate prejudice and inconsistency in the relationship between corporate governance and financial performance. Using different indicators (scores) for corporate governance results in mixed (positive/negative) impacts on firm's financial performances.

Contextually, the bulk of the published research on corporate governance-frim performance relationship was done in the context of developed countries. Variations in the governance mechanisms and arrangements are determined by the differences in firm characteristics and countries. For example, in the U.S. system, discrete shareholders play a significant role, and the primary agency conflict is between owners and managers. Under this system, a significant risk to shareholders is fraudulent financial reporting. Hence, the existing corporate governance mechanisms are tailored to alleviate these agency conflicts (Carcello, Hermanson, \& Ye, 2011; Shawtari et al., 2015). Little is known about the impact of governance practices on firm 
performance in the wake of the 2008/2009 global financial crisis (Ahmed-Haji \&Mubaraq, 2015). Specifically, little evidence is provided in the Middle East in general, and Jordan in particular (Marashdeh, 2014) while the regulators, decision makers and scholars have demonstrated the importance of implementing corporate governance in Jordan (Bawaneh, 2011; Ajeela\&Hamdan, 2011; Hamdan, 2012).

Conversely, in some parts of the world, the scenario may be different from what it is in the US due to certain factors relating to culture, legality, and regulatory traditions etc. As a result of this, the corporate governance mechanisms developed in an Anglo-American context may not fit well in the context of developing countries such as Jordan (Carcello, Hermanson\& Ye, 2011).

In the same vein, firm performance in Jordan is low, and has led to decrease in the level of financial reporting quality, loss of the financial statements' reputation, and it consequently jeopardizes the confidence of shareholders and investors in the shareholding firms (Al-Sraheen, 2014). This has consequently attracted the concerns of the stakeholders (Almajali, Alamro\& Al-Soub, 2012; Shawtari et al, 2017). Therefore, assessment of the impact of corporate governance implementation is very crucial for the monitoring their effectiveness for the case of Jordan. It is apparent that the role of corporate governance is a topic that has gained importance and has been dealt with extensively in both developed and developing nations. It is of significance to note that the increasing awareness of the issue in developed nations may not be completely applicable to the emerging markets (Zeitun, 2006). This is because emerging markets vary from their developed counterparts in several characteristics including their political system, corporate capital structure, corporate governance, ownership structure, taxation system, liquidation law and the financial system. Emerging markets are characterized by less information efficiency, higher volatility, and they are smaller in size, these confines the application of the empirical models proposed for the developed nations.

In addition, it is admitted that the corporate governance is still new as has been introduced mandatorily in 2009. Therefore, assessment of corporate governance taken into consideration enough periods to determine their effectiveness is of paramount importance. This is because prior research on Jordan has focused on single cross sectionperiod in immediately post the issuance and implementation of the code of corporate governance. To the view of researcher, it is important to have enough time to be considered when analyzing the effectiveness of any policy and thereon the impact of corporate governance on performance. Having enough time allows for companies to adapt to the new system and hence their impact could be seen after sometimes. Besides that one of major concern of the cross sectional studies that have been conducted previously lies in their limitation and overlook of the endogeneity problems in the paradox of corporate governance and performance. Thus, study further improves in term of time period and in term of methodological issues.

The weak of firm performance of Jordanian-listed firms is also attributed to weakness in corporate governance practices. The World Bank and IMF in (2004) evaluated the status of corporate governance in Jordan; both concluded that the corporate governance of Jordanian companies remains at a relatively immature stage. Abdullatif and Al-Khadash (2010), Ajeela and Hamdan (2011) and Bawaneh (2011) confirmed these findings. Nimer, Warrad, and Khuraisat (2012) show that the performance of the audit committees in Jordanian-listed firms seems to be ineffective due to the constraints on the audit committee members' work as well as the weak independence of the members. Their results also indicate that the majority members of audit committees often have close relationships with firm management and the board of directors. Abed, Al-Badainah and Serdaneh (2012) show that there is a weakness in the monitoring function of the board of directors of Jordanian firms. They attribute this weakness to the existence of more than 14 members on the board and the dual roles of CEO/chairman. 
These practices are not consistent with the Corporate Governance Code issued by ASE, which recommends that members of a board should not exceed 13 and that the roles of CEO and chairman role should be separated. This means that many Jordanian companies do not comply with ASE-issued corporate governance instructions ASE, Thus, shareholders and investors in Jordan may face increased business risks because of poor implementation of corporate governance systems, weak control systems and non-existent or unclear corporate strategies and objectives (Abdullatif \& Al-Khadash, 2010).

In addition, low-level of firm performance in Jordan has made many firms liquidate and then collapse. According to the Companies Control Department (CCD), the statistics showed that from 2000 to 2011, there were 44 bankruptcy cases in Jordanian companies. 26 companies $(59 \%)$ were from the industrial sector, 15 companies (34\%) from services sector and 3 companies (7\%) from the financial sector (http://www.ccd.gov.jo/2012). Among the liquidated companies in Jordan areMagnesia Company which lost JD130 million (Jodeh, 2006). The consequent effect of the scenarios has already descended on the society with increased unemployment, low investment, and the overall bad economy. This situation has spelt doom to Jordanian economy, because the economy relies heavily on, apart from external aids, taxes from companies. The decrease of financial strength and liquidation of many companies has led to the increase rates of unemployment in the country (Asfor, 2003).

The liquidation of firm has been attributed, among others, to the weak corporate governance practices and weak firm performance (Iskandar et al., 2011).A good number of research (e.g. Abdullatif \& Al-Khadash, 2010; Ajeela\&Hamdan, 2011; Bawaneh, 2011) has confirmed this scenario too.

As a way-out, it has been recommended that some reforms be put introduced to enhance the firm performance. The recommended reforms include introduction of conservative principles, effective corporate governance mechanisms, and the quality of audit (Hamdan, 2011; 2012, Hamdan, Kukrija, Awwad\&Dergham, 2012; Adeyemi\&Fagbemi, 2010).

Moreover, conflicts of interest between managers and other parties to the firms do occur. The reason is that managers effectively do control firms' assets but generally they do not have a significant equity stake in their firms (Berle\& Means, 1932; Jensen \&Meckling, 1976). Due to these conflicts, major companies such as Enron and WorldCom have collapsed (Habbash, 2010). These conflicts cannot be resolved completely through contracts because it is costly, if not impossible; to write and enforce complete contracts (Fama\&Jensen, 1983; Hart, 1995). Thus, in a world with incomplete contracts, corporate governance mechanisms arise to mitigate these conflicts and to assist the firm to protect their investments to ensure continuity. Corporate governance mechanisms such as ownership structure, board of directors, audit committee and audit quality, and so on.differs in terms of their costs and benefits. In this study, the optimal combination of governance mechanisms is chosen to assist the firms in their continuity by limiting the conflicts between corporate managers and shareholders. Such mechanisms are likely to vary systematically across firms because these costs and benefits likely vary with firm characteristics (Leftwich, Watts \& Zimmerman 1981; Agrawal \&Knoeber, 1996; Boone, Field, Karpoff\&Rahega, 2006; Watts, 2006; Shawtari et al. 2017).

Furthermore, one of the major challenges of corporate governance research since its inception has been the definition of measures of good corporate governance. In another words, selection of corporate governance mechanisms that lead to financial efficiency, social legitimacy or more generally goal attainment has become a problem (Schnyder, 2012). In a bid to analyses the impact of corporate governance on different measures of corporate performance, academics and commercial providers have either used individual variables (such as board independence and ownership structure) or have attempted to construct composite measures of corporate governance practices. Despite considerable efforts and sophistication of measures 
and methods, the results so far are surprisingly ambiguous and contradictory (Bhaghat et al., 2008).

As a result, the corporate governance mechanisms in this study will be contextual and firmspecific, given the fact that differences in the governance mechanisms and arrangements are determined by the differences in firm characteristics across countries (Carcello, Hermanson\& Ye, 2011). The context within which a firm operates determines the kind of corporate governance mechanisms to be adopted (Ararat \& Dallas, 2011). Hence, ownership structure, board characteristics, audit committee, internal audit, and auditor quality are the selected corporate governance mechanisms in this study.

Further, an efficient board is capable to enhance corporate governance. This is because efficient board could decrease the agency costs and overcome the conflicts that arise between the management and shareholders. In Jordan, concentrated ownership in Jordan denotes that the majority of firms in the country are led by large shareholders, including families as well as institutional investors (ROSC, 2004). There are implications following this trend of ownership. For instance, there is a possibility of large shareholders establishing power bases through their rights of voting and also by using the policies of firm to impose control on the actions of the managers to cater to their own interests. As a consequence, the agency problem could worsen while the performance of the firm becomes undermined. Nonetheless, having large shareholders could mean that the decisions of management could be monitored more closely owing to these stakeholders 'increased stake in the firm, which in turn would decrease the agency problem and enhance firm performance. The aforementioned could happen. Therefore, the study explores the effect of ownership structure on firm performance.

The economic and financial reforms launched in Jordan were aimed at enhancing the accountability and transparency in the environment of financial so that the country could enhance its confidence in the national economy. There have been issuances and applications of many laws onthe subject of corporate governance. These laws include Securities Law, Insurance Law, Company Law, Competition and Monopoly Law, Commercial Law, Banking Law, Investment Promotion Law and Privatization Law (Al-Jazi, 2007). These laws have caused the increase in foreign investors to the local market. Further, Jordan is inthe top three countries in the Middle East and North Africa (MENA) with respect to bringing in the foreign investment (Al-Muhtaseb, 2009). Hence the effects of characteristics of board on firm performance are examined in this study.

Other factors that influence the measure of corporate governance mechanisms in this study include dearth of empirical studies on the relationship between corporate governance, ownership structure, board characteristics and firm performance, low quality of audit in Jordanian firms (Shanikat\&Abbadi, 2011), and Al-Matari Al-Swidi and Fadzil's (2013) suggestion for the re-examination of the relationship between the experience of internal audit and firm performance.

Empirical gaps in the context of Jordan are very clear. The impact of the mandating corporate governance principles on Jordan stock market companies and their performance is neglected. A very rigorous studies has been overlooked the performance indicators and its linked with overall corporate governance. Moreover, studies have not given any consideration for the comprehensive effects of corporate governance in Jordan. Moreover, to the best of knowledge, factors influencing the performance of Jordan listed companies have also not given any consideration. For example, political system, corporate capital structure, corporate governance, ownership structure, system of taxation, laws of taxation, and financial systems (bank-based in emerging markets like Jordan). It is also evident that emerging markets are characterized by less information efficiency, higher volatility, and they are smaller in size, which confines the empirical models proposed in the developed markets. In addition to the 
above, Jordanian firms have a highly concentrated ownership structure and following the Gulf Crises in 1991 and 2003, the Jordanian economy has been adversely impacted. Therefore, this study contributes by involving the financial sector which deemed as with other countries as a crucial element to the health of the firms (Zeitun, 2006).

In this regard, Al-Malkawi's (2005; Shawtari et al., 2016) study stressed on the lack of empirical study concerning the performance of the firms in emerging markets, especially in the case of Jordan . He added that there have been few studies dedicated to Jordanian firms' ownership structure and hence literature of this kind is still lacking. Finally, the role women on the board has not been examined for the case of Jordan.

\section{CONCLUSION AND FUTURE DIRECTIONS}

This paper aims to investigate the corporate governance for the modern firms and shows how the corporate governance has been developed in the context of Jordan. A highlight on literature review in the area has been examined. Jordan Context of corporate governance and related empirical research has been discussed to show the importance of this mechanism to the development of the stock market of the country and protection of the investors. Jordan has been passed through as series of developments, however, the introduction of mandatory corporate governance principles is the hallmarks of such developments. Empirical research in the context of corporate governance is still at its infancy stage due to the recent mandatory introduction of corporate governance governance guiltiness. Thus, few research areas could be suggested in the context of corporategovernance. The present research suggests comprehensive examination of the factors affecting firm performance in Jordan as a developing country because differences lie between emerging markets and developed ones. The variables affecting firm performance in the former could not necessarily be the same ones affecting the latter. Hence, this study suggests the comprehensive examination of these factors to differentiate whether or not the theories that have been proposed and employed in developed markets can be employed in the emerging markets. Moreover, the role of political influence an important dimension because of its significance to an emerging market such as Jordan. Political influence is suggested to be added to anyanalysis of corporate governance and performance relationship to reflect a significant aspect that reflects the cultural environment of Jordan. Another interested research is on the performance consequences of women's board participation. This is because studies suggest that the diversity of women bring to boards and their distinctive management style improve boards' operation; whereas others note that the limited experience of women in leadership positions and their lesser drive to advance to the top are characteristics that could diminish their effectiveness as board members (Nielsen \& Huse, 2010; Dargnies, 2012). Such diversity of the previous theoretical and empirical evidence stimulates the researcher to suggest this research for the case of new context of Jordan.

\section{REFERENCES}

[1] Ahmed Haji. A. \&Mubaraq, S. (2015). The Implications Of The Revised Code Of Corporate Governance On Firm Performance.Journal Of Accounting In Emerging Economies, 5(3), Pp. $350-380$

[2] Baydoun, N. Maguire, W., Ryan, N., \& Willett, R. (2013). Corporate Governance In Five Arabian Gulf Countries. Managerial Auditing Journal, 28(1), 7-22

[3] Marashdeh, Z. M. S. (2014). The Effect Of Corporate Governance On Firm Performance In Jordan. University Of Central Lancashire, Phd Thesis(March). Retrieved From Http://Jwc.Jxnu.Edu.Cn:8080/Kc/Gsjr/File/The Impact Of Corporate Governance On Firm Performance.Pdf. 
[4] Hamdan, (2012) A. "Factors Affecting Accounting Conservatism When Preparing Corporate Financial Reports: Evidence From Jordan." Jordan Journal Of Business Administration. 8, (1), (2012), 22-41.

[5] Allen, F. (2005).Corporate Governance In Emerging Economies.Oxford Review Of Economic Policy, 21(2), 164-177.

[6] Kearney, C. (2012). Emerging Markets Research: Trends, Issues And Future Directions. Emerging Markets Review, 13(2), 159-183

[7] Tsamenyi, M., Enninful-Adu, E., \&Onumah, J. (2007). Disclosure And Corporate Governance In Developing Countries: Evidence From Ghana. Managerial Auditing Journal, 22(3), 319-334.

[8] Carcello, Neal (2003), Audit Committee Characteristics And Auditor Dismissals Following "New" Going-Concern Reports, The Accounting Review 78, 95-117.

[9] Ararat, M., \& Dallas, G. (2011). Corporate Governance In Emerging Markets: Why It Matters To Investors-And What They Can Do About It.

[10] Fan, J. P., Wei, K., \& Xu, X. (2011). Corporate Finance And Governance In Emerging Markets: A Selective Review And An Agenda For Future Research. Journal Of Corporate Finance, 17(2), 207-214.

[11] Claessens, S., \&Yurtoglu, B. B. (2013). Corporate Governance In Emerging Markets: A Survey. Emerging Markets Review, 15, 1-33.

[12] Tarraf, H. (2011). The Role Of Corporate Governance In The Events Leading Up To The Global Financial Crisis: Analysis Of Aggressive Risk-Taking. Global Journal Of Business Research, 5(4), 93-105.

[13] Reed, D. (2002). Corporate Governance Reforms In Developing Countries. Journal Of Business Ethics, 37(3), 223-247.

[14] Mallin, C. A. (2004). Corporate Governance. 1th Edn, Oxford University Press, Incorporated.

[15] Solomon, J. \& Solomon, A. (2004). Corporate Governance And Accountability, John Wiley, New York, Ny.

[16] Ase. (2012). Amman Stock Exchange. Retrieved From: Http://Www.Ase.Com.Jo/En/Date

[17] Ase Amman Stokc Exchang Corporate Governance Council, A. C. G. (2007). Principlesof Good Corporate Governance And Best Practicerecommendations

[18] Almajali, A. Y., Alamro, S. A. \& Al-Soub, Y. Z. (2012). Factors Affecting The Financial Performance Of Jordanian Insurance Companies Listed At Amman Stock Exchange. Journal Of Management Research, 4(2), 266-289.

[19] Al-Sraheen, D. A. A. D., \& Nawwaf, O. (2014). The Relationship Between Corporate Governance Mechanisms and Company Attributes and Accounting Conservatism Of Jordanian Listed Companies (Doctoral Dissertation, Universiti Utara Malaysia).

[20] Al-Muhtaseb, B. (2009). The Impact of Foreign Direct Investment on The Economic Growth Of Jordan (1990-2006). Dirasat: Administrative Sciences, 36(2).

[21] Siddiqui, S. S. (2014). The Association Between Corporate Governance and Firm PerformanceA Meta-Analysis. Available at Ssrn 2424592. 
Khaleel Al-Daoud, Alaa alhorani, Mohammad dabaghia, Zeyad Alkhazali and Ghiath Altrjman

[22] Shawtari, F. A., Har Sani, M. M., Abdul Rashid, H. M., \& Salem, M. A. (2015). Corporate governance mechanisms and unmanaged earnings: Empirical evidence from Malaysian government linked companies. Corporate Board: Role Duties \& Composition, 11(2), 98-110.

[23] Ahmed Haji. A. \&Mubaraq, S. (2015). The Implications Of The Revised Code Of Corporate Governance On Firm Performance.Journal Of Accounting In Emerging Economies, 5(3), Pp. $350-380$.

[24] Shawtari, F. A., Salem, M. A., Hussain, H. I., Alaeddin, O., \& Thabit, O. B. (2016). Corporate governance characteristics and valuation: Inferences from quantile regression. Journal of Economics, Finance and Administrative Science, 21(41), 81-88.

[25] Ujunwa, A. (2012). Board Characteristics And The Financial Performance Of Nigerian Quoted Firms. Corporate Governance: The International Journal Of Business In Society, 12(5), 656674.

[26] Kyereboah-Colema, A. (2007). Corporate Governance And Firm Performance In Africa : A Dynamic Panel Data Analysis. Studies In Economics And Econometrics, 32(2), 1-24.

[27] Bawaneh, S. (2011). The Effects Of Corporate Governance Requirements On Jordan Banking Sector. International Journal Of Business And Social Science,2(9), 130-140.

[28] Ajeela, E., \& Hamdan A. (2011). The Relationship Between Corporate Governance And Earnings Management: Evidence From Jordan. Arab Journal Of Administrative Sciences, $17(2), 1-28$.

[29] Zeitun, R. M. (2006). Firm Performance And Default Risk For Publicly Listed Companies In Emerging Markets: A Case Study Of Jordan (Doctoral Dissertation, University Of Western Sydney).

[30] Nimer, K., Warrad, L., \& Khuraisat, O. (2012). The Effect Of Audit Committee's Effectiveness On Dividend Payout Policy: Evidence From The Jordanian Firms. International Journal Of Business And Management, 7(7), 172.

[31] Shawtari, F. A., Har Sani Mohamad, M., Abdul Rashid, H. M., \& Ayedh, A. M. D. (2017). Board characteristics and real performance in Malaysian state-owned enterprises (SOEs). International Journal of Productivity and Performance Management, 66(8), 1064-1086.

[32] Mohamad, M. H. S., Rashid, H. M. A., \& Shawtari, F. A. M. (2012). Corporate governance and earnings management in malaysian government linked companies: the impact of GLCs' transformation policy. Asian review of Accounting, 20(3), 241-258.

[33] Abed, S., Al-Badainah, J., \& Serdaneh, J. A. (2012). The Level Of Conservatism In Accounting Policies And Its Effect On Earnings Management.International Journal Of Economics And Finance, 4(6), 78 .

[34] Shawtari, F. A., Saiti, B., Mohamad, M. H. S., \& Rashid, H. M. A. (2017). Does intense monitoring matter? A quantile regression approach. Borsa Istanbul Review, 17(2), 75-85.

[35] Hamdan, A. M. M., Kukrija, G., Awwad, B. S. A. L., \& Dergham, M. M. (2012). The Auditing Quality And Accounting Conservatism. International Management Review, 8 (2), 33-50

[36] Adeyemi, S. B., \& Fagbemi, T. O. (2010). Audit Quality, Corporate Governance And Firm Characteristics In Nigeria. International Journal Of Business And Management, 5(5), $169 .$. 
[37] Berle, A., \& Means, G. (1932). The Modern Corporation And Private Property. New York: Macmillan.

[38] Habbash, M. (2010). The Effectiveness Of Corporate Governance And External Audit On Constraining Earnings Management Practice In The Uk (Doctoral Dissertation, Durham University).

[39] Hart, O. (1995). Firms, Contracts, And Financial Structure. Clarendon Press.eftwich, R. W., Watts, R. L., \& Zimmerman, J. L. (1981). Voluntary Corporate Disclosure: The Case Of Interim Reporting. Journal Of Accounting Research, 50-77.

[40] Boone, A., Field, L., Karpoff, J., \& Rahega, C. (2006). The Determinants Of Corporate Board Size: An Empirical Analysis. Working Paper, Vanderbilt University.

[41] Watts, R. L. (2006). What Has The Invisible Hand Achieved?. Accounting And Business Research, 36(Sup1), 51-61.

[42] Rosc. (2005). Report On The Observances Of Standards And Codes, Corporate Governance Country Assessment (Electronic Version). Amman-Jordan.

[43] Shanikat, M., \& Abbadi, S. S. (2011). Assessment Of Corporate Governance In Jordan: An Empirical Study. Australian Accounting Business And Finance Journal, 5(3), 91-1063 